This is a self-archived version of an original article. This version may differ from the original in pagination and typographic details.

Author(s): Ryynänen, Sanna

Title: Puhummeko nyt rasismista?

Year: 2020

Version: Published version

Copyright: @ 2020 Media- ja viestintätieteellinen seura MEVI ry

Rights: CC BY-NC 4.0

Rights url: https://creativecommons.org/licenses/by-nc/4.0/

Please cite the original version:

Ryynänen, S. (2020). Puhummeko nyt rasismista?. Media ja viestintä, 43(4), 326-344.

https://doi.org/10.23983/mv.100619 


\title{
Artikkeli
}

\section{Puhummeko nyt rasismista?}

\begin{abstract}
Rasismi-sanaan liittyy epävarmuutta siitä, mitä se on ja missä yhteyksissä sitä voi käyttää. Yksi syy hämmennykseen on se, että sanaa on opittu varomaan. Myös osa rasismintutkijoista käyttää tutkimuksessaan muita termejä välttyäkseen rasismi-sanan aiheuttamalta vastareaktiolta. Kun rasismia on ryhdytty korvaamaan "turvallisemmilla" termeillä, niiden merkityssisällöt ovat alkaneet hämärtyä. Tutkimuskirjallisuudessa käytetään rinnakkain ja jopa samaa tarkoittavina syrjintää, toiseuttamista, ksenofobiaa, rodullistamista ja rasismia ilman, että termien välisiä merkityseroja useinkaan pohditaan tai avataan kunnolla. Sanahämmennyksen seurauksena rasismikeskustelua käydään tutkimuksessa - ja myös laajemmin yhteiskunnassa - ilman selkeää käsitystä siitä, miten ilmiökentän termit tulisi ymmärtää ja miten niitä käyttää. Tässä artikkelissa tarkastelen sitä, miten rasismi ja sen lähikäsitteet on nähty suomenkielisessä mediatutkimuksen kirjallisuudessa. Sen jälkeen käyn läpi keskeisten termien eroja ja merkityssisältöjä suomalaisen ja kansainvälisen tutkimuskirjallisuuden pohjalta. Päämääränä on helpottaa termien käyttöön liittyvää epävarmuutta ja epätietoisuutta.
\end{abstract}

AVAINSANAT: rasismi, rodullistaminen, ksenofobia, toiseuttaminen, syrjintä.

M aahanmuuton lisäännyttyä ja oikeistopopulismin kasvatettua suosiotaan media joutuu yhä useammin tekemisiin rasismin ja siihen kytkeytyvien ilmiöiden kanssa. Toimittajat tekevät juttuja maahanmuuttoon liittyvistä ongelmista, haastattelevat rasistisia poliitikkoja ja tuovat esille vähemmistöjen kohtaamaa rasismia. Rasismi on kuitenkin vaikea aihe: Eduskunnassa ja oikeussaleissa käydään keskusteluja, joissa rasismi on läsnä mutta sen osoittaminen tai todentaminen on vaikeaa. Sosiaalisessa mediassa rasismi kätketään kiertoilmauksiin ja näennäiseen tahattomuuteen. Toimittajien - samoin kuin mediatutkijoiden - olisi kyettävä hahmottamaan, mikä on rasismia, mikä ei. Milloin jotain uskaltaa sanoa rasismiksi? Millä perusteella? Olisko parempi puhua ksenofobiasta? Tai syrjinnästä? Toiseuttamisesta? Miten nämä käsitteet eroavat rasismista tai toisistaan? Mitä eri käsitteet korostavat? Mitä ne hämärtävät?

Tässä artikkelissa katson, miten suomenkielinen mediatutkimus ymmärtää ja määrittelee käsitteet rasismi, rodullistaminen, ksenofobia, toiseuttaminen ja syrjintä. Sen 
jälkeen pyrin selkeyttämään niitä käymällä läpi eri tieteenaloilla tehtyä suomalaista ja kansainvälistä rasismintutkimusta. Tuon myös esiin käsitteiden käyttöön liittyviä sudenkuoppia.

\section{Keskeisiä käsitteitä ei määritellä}

Kävin läpi 43 suomenkielistä mediatutkimuksen tekstiä, jotka ovat ilmestyneet vuosina 1992-2018. Mukana ovat tutkimuskauden keskeisimmät tieteelliset tekstit, jotka käsittelevät suomalaisen median suhtautumista maahanmuuttajiin, etnisiin vähemmistöihin tai pakolaisiin. (Käytän tässä sanaa pakolainen tarkoittamaan kotimaastaan paennutta ihmistä, en pakolaisstatuksen saanutta ihmistä. Sana kattaa siten myös turvapaikanhakijat.) Otannan ulkopuolelle on jätetty pro gradu- ja kandidaatintutkielmat sekä ammattikorkeakoulujen opinnäytetyöt. Varhaisimmat tekstit ovat 1990-luvulta, jolloin Suomessa ryhdyttiin laajemmin tarkastelemaan median suhdetta maahanmuuttoon, etnisiin vähemmistöihin ja rasismiin (Horsti 2005, 11; Maasilta 2012, 13-14; Pietikäinen \& Luostarinen 1996, 178). Teksteistä 37 on artikkeleita, joista 35 on ilmestynyt toimitetuissa teoksissa ja 2 tieteellisissä lehdissä. Loput 6 ovat kirjoja. Tutkittavat tekstit on haettu Finna-hakupalvelusta, josta löytyvät kaikki yliopistokirjastojen kokoelmissa olevat kirjat ja lehdet. Hakulausekkeessa on yhdistetty hakutermi "media*" tai "lehdist*" hakutermeihin "rasis*", "rodullist*", "toiseu*", "syrjin*", "vieraspel*", "vierasvih*", "muukalaispel*", "muukalaisvih*", "ksenofobia*" ja "xenofobia*". Aineisto täydentyi tutkimuksen edetessä, kun julkaisujen lähdetiedoista löytyi lisää aiheeseen liittyviä kirjoja ja artikkeleita.

Luin tekstit hakien niistä tässä artikkelissa käsiteltäviä termejä. Katsoin, oliko termit määritelty tai oliko niitä muulla tavoin avattu tai selitetty. Tutkituista 43 tekstistä 32 mainitsi ainakin jonkin termeistä rasismi, rodullistaminen, ksenofobia, toiseuttaminen tai syrjintä, mutta vain kuusi niistä määritteli käyttämiään termejä. Yksi määritellyistä termeistä oli aina rasismi: sen siis määritteli kuusi tekstiä, mikä ei ole kovin paljon, sillä sana mainittiin 31:ssä tekstissä. Rodullistamisen mainitsi kolme tekstiä, joista yksi määritteli sen. Ksenofobia mainittiin 11 tekstissä ja määriteltiin neljässä. Viidessä tapauksessa mainittiin lisäksi sanan suomenkielinen vastine: muukalais-, vieras- tai ulkomaalaispelko tai -viha. Kahdessa tekstissä käytettiin pelkästään suomenkielistä termiä. Toiseuttaminen-sanaa käytti kolme tekstiä. Sen lisäksi samaa ilmiötä käsitteli viisi tekstiä termillä "toiseus" ja seitsemän tekstiä sanapareilla "me-he", "me-muut", "me-toiset" tai "vieraus-samuus". Näistä 15 tekstistä ilmiötä avasi viisi. Syrjinnän mainitsi kahdeksan tekstiä, mutta niistä yksikään ei määritellyt sitä.

Rasismin ilmiökentän termejä ei siis mediatutkimuksessa juurikaan avata tai määritellä. Käsitteiden avaaminen olisi kuitenkin tarpeen. Rasismintutkijoilla on erilaisia näkemyksiä esimerkiksi siitä, onko syrjintä rasismin synonyymi, sen yläkäsite vai alakäsite (ks. esim. Fitzgerald 2016, 17; Kortteinen \& Makkonen 2000, 10-11; Puuronen 2011, 51; Wodak \& Reisigl 2015, 578). Ksenofobia taas on toisinaan nähty rasismin synonyyminä, toisinaan sen "hyväntahtoisena" muotona (ks. esim. Jaakkola 2005, 12; 
Makkonen 2000, 27, 52-53; Vehmas 2005, 97). Edes kansainvälisesti ei löydy monia sellaisia tekstejä, joissa termien välisiä eroja tai suhteita olisi kunnolla pohdittu tai avattu (joidenkin termien vertailua esim. Bernasconi 2014, 6; Tafira 2011, 115; Taguieff 2008).

Käsitteiden välisiä eroja hämärtää entisestään se, että rasismi-sanaa varotaan, minkä vuoksi sen tilalla käytetään muita sanoja, jotka eivät kuitenkaan täysin vastaa rasismi-käsitteen sisältöä. Tutkijat Philomena Essed (2004, 120-124) ja Teun A. van Dijk $(1999,147)$ ovat kertoneet, että heidän kollegansa ovat tutkimuksissaan korvanneet rasismin sellaisilla termeillä kuin syrjintä, ennakkoasenteet ja stereotypiat välttyäkseen rasismi-sanan herättämiltä vastareaktioilta. Suomalaisessa rasismintutkimuksessa sanaa on korvattu muun muassa termeillä syrjintä, muukalaispelko ja suvaitsemattomuus (Rastas 2005, 69). Kiertoilmausten käyttö vaikeuttaa rasismiilmiön ymmärtämistä: onko muukalaispelko sama asia kuin rasismi? Onko kaikki etnisiin vähemmistöihin kohdistuva suvaitsemattomuus rasismia?

Käyn läpi viisi rasismintutkimuksen keskeistä käsitettä: rasismi, rodullistaminen, ksenofobia, toiseuttaminen ja syrjintä. Jokaisen kohdalla selvitän, miten käsitettä on käytetty suomalaisessa mediatutkimuksessa, onko sitä määritelty tai avattu ja miten. Sen jälkeen käyn läpi kunkin käsitteen merkityssisältöä suomalaisen ja kansainvälisen rasismintutkimuksen avulla. Joidenkin käsitteiden kohdalla tuon lisäksi esiin ongelmia, joita niiden käyttämiseen liittyy. Rasismintutkimusta on tehty eniten sosiologian alalla, josta tulee myös iso osa tämän artikkelin lähteistä.

\section{Rasismi}

Rasismin käsittely alkoi vakiintua osaksi suomalaista mediatutkimusta noin kolmekymmentä vuotta sitten (Horsti 2005, 11; Maasilta 2012, 13-14; Pietikäinen \& Luostarinen 1996, 178). Noiden kolmenkymmenen vuoden aikana koko rasismintutkimuksen kenttä on kehittynyt nopeasti ja syventänyt käsitystä siitä, mitä rasismi on ja miten se vaikuttaa yhteiskunnassa (Bonilla-Silva 2006; Bulmer \& Solomos 2004, 8; Coates 2011; Essed 1991; Fitzgerald 2016, 10-11). Alan kehitysvaiheet näkyvät myös suomalaisessa mediatutkimuksessa: 1990-luvun alussa se ymmärsi rasismin vielä rotujen ja ihonvärin kautta (esim. Melin 1992, 45). Vuosikymmenen puolivälin jälkeen huomattiin, että rasismi pohjautui usein ulkonäöllisten piirteiden sijaan kulttuurisiin ryhmittelyihin (esim. Helminen 1996, 40). 2000-luvun alussa mediatutkimuksen teksteissä mainitaan myös yhteiskunnallisiin järjestelmiin kietoutunut institutionaalinen rasismi (esim. Raittila 2004, 30) ja jokapäiväisissä kohtaamisissa tapahtuva arkipäivän rasismi (esim. emt., 31; Pietikäinen 2002, 19).

Huomionarvoista on se, että mediatutkijat käyttävät termiä rasismi vain kirjojensa ja artikkeliensa otsikoissa tai teoriataustassa. Kun he siirtyvät käymään läpi oman tutkimuksensa tuloksia ja havaintoja, rasismi-termi katoaa. Sen tilalle tulevat muun muassa myönteisyys/kielteisyys, marginalisointi, vieraus/samuus ja negatiiviset stereotypiat. 
Rasismin voi määritellä seuraavasti: se on ennakkoluuloista, vihamielistä, holhoavaa tai alentuvaa asennoitumista tai käytöstä toisia ihmisiä kohtaan sillä perusteella, että noiden ihmisten katsotaan kuuluvan johonkin tiettyyn etniseen ryhmään (Ryynänen s.d.).

Rasismi jaetaan tyypillisesti kahteen osaan, ideologiaan ja toimintaan. Itse käytän sanoja ideologia ja ilmenemismuodot, sillä rasismi näkyy toiminnan lisäksi muun muassa ajatuksina ja asenteina. Rasismin ideologia on eriarvoistava ajattelutapa, joka läpäisee maailmankuvamme ja jonka näkyviä (ja tuntuvia) seurauksia ovat rasismin ilmenemismuodot. Näitä ilmenemismuotoja ovat muun muassa ennakkoasenteet, toiseuttaminen, rodullistaminen, syrjintä, viha ja väkivalta. (Balibar 1991a, 17-18; Fitzgerald 2016, 10-11; Kortteinen \& Makkonen 2000, 10; Pietikäinen 2000, 42; Ryynänen s.d.; Tafira 2011, 116; Taguieff 2008, 228, 232; Taras 2012, 14). Erittelen jäljempänä näistä ilmeneismuodoista toiseuttamista, rodullistamista ja syrjintää ja pohdin sitä, missä tapauksissa ksenofobian voi nähdä rasismin ilmenemismuotona. Aloitan kuitenkin avaamalla rasismin ideologiaa.

Kuvio 1: Rasismin ideologia.

\section{RASISMIN IDEOLOGIA}

\section{Erottelu}
a. Ryhmittely
b. Luonnehdinta
c. Pysyvyys
d. Erojen korostaminen

2. Ylemmyys

3. Epäoikeudenmukaisuuden oikeuttaminen

Olen selkeyden vuoksi jaotellut rasismin ideologian kolmeen osaan: erotteluun, ylemmyyteen ja epäoikeudenmukaisuuden oikeuttamiseen (Ryynänen s.d.).

\section{Erottelu}

Erottelussa ihmisten nähdään kuuluvan erillisiin ryhmiin, joita voidaan arvioida ja arvottaa. Erottelun voi ajatella koostuvan neljästä osa-alueesta:

a) Ryhmittely. Ihmisten katsotaan kuuluvan erilaisiin rodullisiin tai kulttuurisiin ryhmiin. Ryhmät määrittyvät sellaisten asioiden perusteella kuin kieli, kansallisuus, uskonto, ulkonäkö tai vaatetus. (Melin 1992, 45; Pietikäinen 2000, 43-44; Raittila \& Kutilainen 2000, 5; Sinokki 2017a, 11; Tafira 2011, 114; Taguieff 2008, 232; Vehmas 2005, 97.) 
b) Luonnehdinta. Ryhmien jäseniä luonnehditaan ja määritellään liittämällä heihin piirteitä ja ominaisuuksia, jotka eivät liity varsinaisten ryhmärajojen hahmottamiseen. Näiden piirteiden katsotaan kuvaavan oleellisesti kaikkia ryhmän jäseniä. (Banton \& Miles 1996, 310; Bulmer \& Solomos 2004, 8; Taguieff 2008, 232; Wodak \& Reisigl 2015, 578-579.)

c) Pysyvyys. Ryhmän jäseniin liitettyjen piirteiden, taipumusten ja tapojen katsotaan olevan muuttumattomia ja pysyviä: ryhmän jäsenet ovat tietynlaisia, ovat aina olleet sellaisia ja tulevat aina sellaisina pysymään (Bonilla-Silva 2006, 39-40; Keskinen 2009a, 19; Makkonen 2000, 6; Taguieff 2008, 232; Taira 2008, 214; Wodak \& Reisigl 2015, 578-579).

d) Erojen korostaminen. Ryhmien välillä nähdään olevan merkittäviä, ylittämättömiä eroja, joiden vuoksi ryhmien toimivaa yhteiseloa pidetään vaikeana tai mahdottomana (Balibar 1991a, 20-21; Bracalenti \& Braham 2003, xvii; Huttunen ym. 2005, 27; Taguieff 2008, 232-233).

2. Ylemmyys.

"Me" olemme parempia kuin "ne". Ne ovat epäluotettavia, laiskoja, moraalittomia, röyhkeitä, likaisia ja niin edelleen. (Banton \& Miles 1996, 310; Bonilla-Silva 2006, 39-40; Helminen 1996, 40; Pietikäinen 2002, 19; Pöyhtäri \& Kantola 2013, 42; Taguieff 2008, 232-233.) Me sen sijaan olemme normaaleja - sellaisia kuin niidenkin pitäisi olla. Mutta sellaisia niistä ei koskaan tule, sillä ne pysyvät aina samanlaisina.

3. Epäoikeudenmukaisuuden oikeuttaminen.

Koska "ne" ovat niin epämiellyttäviä, huonosti käyttäytyviä ja epäluotettavia, ne on pidettävä hallinnassa. Toisaalta, koska "meillä" ei ole niitä puutteita ja vikoja, jotka niille ovat niin luonteenomaisia, ansaitsemme - ja asianmukaisesti olemme myös saaneet - erilaisia etuoikeuksia. (Coates 2011, 251; Fitzgerald 2016, 91; Helminen 1996, 40; Kortteinen \& Makkonen 2000, 10-11; Melin 1992, 45; Taguieff 2008, 232.)

\section{Rodullistaminen}

Tätä artikkelia varten katsotuissa mediatutkimuksissa rodullistaminen-termi esiintyi ensimmäistä kertaa Pentti Raittilan väitöskirjassa Venäläiset ja virolaiset suomalaisten toisina (2004, 23). Raittilan mukaan rodullistamisessa inmisen ulkoisiin piirteisiin yhdistetään muita piirteitä, jotka liittyvät esimerkiksi älykkyyteen tai kyvykkyyteen. Suvi Keskinen käytti artikkelissaan "Me" ja "muut"? Kunniaan liittyvä väkivalta median kuvauksissa (2009a, 19) samasta ilmiöstä termiä kulttuuristaminen. Keskisen termivalinta ottaa huomioon nykyisen tavan käyttää kulttuuria samanlaisena muuttumattomana kategoriana, jollaisena rotu toimi menneinä vuosisatoina. Lisäksi kaksi tekstiä mainitsi rodullistamisen avaamatta tai määrittelemättä sitä tarkemmin. Esimerkiksi Pöyhtärin 
ja Kantolan $(2013,38)$ tekstissä termi esiintyy kerran, lauseessa: "Median halukkuus ja kyvykkyys haastaa rodullistavia ja rasistisia puhetapoja on ollut rajallinen [...]".

Rodullistamisen taustalla on 1700-luvun lopulla syntynyt rotuoppi (Isaksson \& Jokisalo 2005, 96-97). Yli sadan vuoden ajan monet tutkijat uskoivat, että inmiskunta olisi jaettavissa selkeisiin roturyhmiin, mutta lopulta tehtävä osoittautui mahdottomaksi. Roturyhmät jäsentyivät eri tavalla riippuen siitä, mihin piirteeseen kiinnitettiin huomiota. Lisäksi missään niin kutsutuissa rodullisissa piirteissä ihmisten väliset erot eivät ole jyrkkiä ja tarkkarajaisia vaan liukuvia. Meidät voidaan laittaa riviin esimerkiksi ihon tummuusasteen mukaan, mutta rivissä ei ole selkeää kohtaa, jossa yksi ryhmä muuttuisi toiseksi. Ja vaikka rivistä erotettaisiin jokin pätkä esimerkiksi suhteellisen tummaihoisia henkilöitä, samaan ryhmään valikoituisi ihmisiä, joiden juuret voisivat juontaa yhtä hyvin eteläiseen Afrikkaan kuin Australiaan tai Itä-Intiaankin. Ihmiset ovat myös aina vaeltaneet, muuttaneet, tavanneet toisia ihmisryhmiä ja saaneet lapsia keskenään, joten erillisiä roturyhmiä, joiden perimälinjat olisivat ammoisista ajoista pysyneet sekoittumattomina, ei ole mahdollista löytää. (Blackburn 2000, 10; Malik 2008, 17-19, 36, 45, 100; Puuronen 2011, 50; Sinokki 2017a, 27; van den Berghe 1996, 296-297.)

Vaikka tiede luopui rotujen käsitteestä, säilyi ihmisten usko siihen, että erinäköiset ihmiset ovat keskenään erilaisia. Nykyään rodullistettujen ryhmien väliset jakolinjat asettuvat usein vanhojen roturyhmien sisälle. Esimerkiksi Euroopassa on viime vuosikymmeninä haluttu tehdä eroa valtaväestön ja muun muassa juutalaisten, romanien tai Lähi-idästä tulleiden maahanmuuttajien välille, vaikka vanhoissa rotuluokitteluissa nämä ryhmät olisivat yleensä kuuluneet samaan kaukasialaiseen rotuun. Rodullistaminen perustuukin usein niin sanottujen rodullisten piirteiden lisäksi tai sijasta esimerkiksi uskontoon, maahanmuuttajataustaan, pukeutumiseen tai kieleen. Usein puhutaan eri etnisyyksistä tai kulttuureista, jolloin ryhmittelyn perusteena voivat olla melkein mitkä tahansa syntyperään tai elinympäristöön liittyvät tekijät. (Balibar 1991b, 221-222; Blackburn 2000, 6; Goldberg 1993, 73-76; Pietikäinen 2000, 34, 42; Sinokki 2017b, 274.)

Rotuoppeihin liittyi ryhmien sijoittaminen huonommuus-paremmuus-akselille, sillä kolonialismin aikakaudella rotuajattelua käytettiin oikeuttamaan toisten, alemmiksi käsitettyjen ihmisryhmien alistaminen, orjuuttaminen ja tappaminen (Isaksson \& Jokisalo 2005, 38-91; Malik 2008,140-145; Miles 1994, 35-50). Rodullistaminen-termissä on mukana rotu-sanaan sisältynyt ajatus huonommuudesta ja paremmuudesta, mutta toisin kuin rotu, rodullistaminen-termi huomioi sen, että rotujaottelu on ihmisen aktiivisesti synnyttämä konstruktio: rodut eivät ole luonnollisia ryhmiä, jotka olisi vain havaittu ja havainnoitu, vaan ne ovat tietoisesti rodullistamisen kautta luotuja (Miles 1994, 111; Puuronen 2011, 21-22).

Ihmisten lisäksi myös tapahtumat, asiat tai ilmiöt voivat olla rodullistettuja (Murji \& Solomos 2005, 3; Puuronen 2011, 21). Suomessa muun muassa seksuaalirikokset on rodullistettu tekemällä niistä maahanmuuttajakysymys, alkoholismi on nähty saamelaisongelmana ja näpistely romani-ilmiönä. Kun jotkin asiat rodullistetaan, niitä käsitellään tiettyihin ryhmiin liittyvinä ja samalla luodaan kuvaa, että ilman noita ryhmiä myöskään ongelmaa tai ilmiötä ei juurikaan olisi. 


\section{Toiseuttaminen}

Aineiston teksteissä toiseus-termi tulee ensimmäisen kerran vastaan Karina Horstin artikkelissa Media ohittaa "toisen" vuodelta 2000. Toiseudesta ja samaa asiaa tarkoittavista sanapareista me-he, me-muut, me-toiset ja vieraus-samuus tuli yleisin mediatutkimuksissa käytetty näkökulma rasismiin vuosien 2000 ja 2008 välillä. Toiseutta kuvattiin erilaisuudeksi tai vieraudeksi, ja määritelmissä korostettiin, että toiseudelle on olennaista huonommuus: "toinen" on jotain alempiarvoista tai vähemmän kuin "me" (Hiltunen 2007, 110; Raittila 2004, 17-18). Sen sijaan kansainvälisessä tutkimuksessa yleisempää toiseuttaminen-termiä (engl. othering) käytettiin vain kolmessa tekstissä.

Toiseuttamisessa keskeistä on erilaisuuden rakentaminen ja osoittaminen. Ajatellaan - ja usein myös omalla toiminnalla osoitetaan - että joku ei kuulu "meihin". Toisaalta on olemassa myös sellaista eron tekemistä, joka ei ole luonteeltaan rasistista vaan tähtää identiteetin rakentamiseen tai me-hengen luomiseen. Tällaisissa tapauksissa en käyttäisi termiä toiseuttaminen (vrt. Boréus 2006, 420) vaan puhuisin esimerkiksi ryhmäidentiteetin luomisesta tai vahvistamisesta. Näin ei hämärtyisi se, mikä on rasistista toiseuttamista ja mikä harmitonta ryhmäkäyttäytymistä. Raja näiden välillä kulkee siinä, millä perusteilla ryhmittelyt tehdään ja kuinka paljon toisesta ryhmästä luoduille mielikuville annetaan totuusarvoa. Moni tietää, millaisia naapurikaupungin ihmiset ovat - vähän yksinkertaisia, huonoja autoilijoita, säälittäviä jääkiekkoilijoita, pihejä ja niin edelleen. Mutta jos tapaamme jonkun naapurikaupungista, emme oikeasti oleta hänen olevan huono autoilija tai pihi. Vaikka melkein uskomme siihen mielikuvaan, jonka olemme naapuripitäjän ihmisistä luoneet, tiedämme myös, että kuva on stereotyyppinen ja liioiteltu. Toiseuttamisessa stereotyyppisistä mielikuvista tulee faktoja. (Hämeen-Anttila 2004, 8-9; Löytty 2005, 162; Ryynänen s.d.)

Toiseuttaminen on usein hyväntahtoista ja tahatonta. Jos ihminen ei vastaa mielikuvaamme tyypillisestä suomalaisesta, häneltä tiedustellaan, mistä hän on kotoisin. Kun hän vastaa, että Helsingistä, kysytään: "Niin mutta alun perin?" Tai hänelle ryhdytään automaattisesti puhumaan englantia. Tai selitetään, miten "meillä" tehdään asiat. Mutta vaikka toiseuttamisella ei olisi tarkoitus loukata, se on kuitenkin rasismia. Ja tämän päivän rasismi on hyvin usein juuri tätä: hienovaraista, jatkuvaa, jokapäiväistä - ja usein tahatonta - osoittamista, että joku ei ole suomalainen, eurooppalainen, yksi meistä. ${ }^{1}$ (Adam 2015, 453-454; Trepagnier 2011.) Jos tällaista erottelevaa käyttäytymistä pidetään vain toiseuttamisena, erotuksena niin sanotusta oikeasta rasismista, väheksytään sen vaikutuksia rodullistetuille. Kun ghanalais-brittiläinen kirjoittaja ja juontaja Afua Hirsch koetti Pledge- ohjelmassa kertoa niistä mikroaggression muodoista, joita hän kohtaa päivittäin Isossa-Britanniassa, hänen valkoihoiset keskustelutoverinsa ojensivat häntä: "Jos se on hyväntahtoista, se ei ole rasismia." ${ }^{2}$ Ja koska se ei ole rasismia, on turhaa herkkähipiäisyyttä ottaa siitä nokkiinsa.

Sen, milloin jokin teko on rasismia, täytyy olla uhrin määrittelemää. Jos määrittelyn tekevät ne, jotka eivät itse koe rasistista käytöstä, he päätyvät vähättelemään rasismin merkitystä ihmisen hyvinvoinnille ja ylenkatsomaan rasismin hienovaraisia muotoja. Kuitenkin noilla hienovaraisilla muodoilla on valtava voima, sillä ne tulevat vastaan aina ja 
kaikkialla, niiltä ei voi suojautua, eikä niitä ole samalla tavalla helppoa ottaa puheeksi kuin avointa vihamielisyyttä. Jos yrittää, seurauksena on usein loukkaantuminen: ei ole reilua väittää rasismiksi sitä, jos toinen vain kysyy, haluaa auttaa tai vitsailee. (Baltzar 2018, 82-83; Brown 2010, 7; Essed 1991, 11; Lehtonen 2009, 111-112; Sinokki 2017a, 17-18.)

\section{Syrjintä}

Syrjintä-termi mainittiin kahdeksassa tekstissä mutta sitä ei avattu tai määritelty niistä missään. Monesti syrjintä esiintyi rasismi-termin rinnalla ikään kuin täydentämässä ilmiökenttää. Esimerkiksi Raittila ja Kutilainen (2000, 5-6) kirjoittavat: "Jos ... käsitellään rasismia ja etnistä syrjintää vain konfliktien ja ongelmatilanteiden yhteydessä ..." ja Horsti $(2013,310)$ : "[T]arkoitus on estää syytökset rasismista ja syrjinnästä." Toisinaan taas syrjintää käytettiin rasismin synonyyminä.

Syrjintä tarkoittaa, että jotakuta kohdellaan epäsuotuisammin kuin jotakuta muuta ilman hyväksyttävää perustetta (hyväksyttävä peruste on esimerkiksi se, että alle 120 senttimetriä pitkää lasta ei päästetä sellaisiin huvipuistolaitteisiin, joista hän saattaisi pudota). Syrjintä voi olla välitöntä tai välillistä. Välitöntä syrjintää on esimerkiksi se, jos yritys ei palkkaa etnisiin vähemmistöihin kuuluvia henkilöitä, ja välillistä syrjintää se, jos yhtiö edellyttää työnhakijalta täydellistä suomen kielen taitoa, vaikka työn suorittamisen kannalta sellainen ei ole tarpeellista. (Anttonen 2009, 21-22; Kortteinen \& Makkonen 2000, 8-9; Makkonen 2000, 9-10; Puuronen 2011, 51-52.)

Toisinaan syrjintä voi olla seurausta olosuhteista, joihin ei sisälly syrjinnän tarkoitusta, esimerkiksi silloin, kun ravintolaan pääseminen edellyttää portaiden kiipeämistä. Tuolloin liikuntavammaiset ihmiset tulevat syrjityiksi. (Scheinin 1996, 11.) Tämän päivän rasismissa on usein kyse tällaisesta tarkoituksettomasta syrjinnästä. Epätasa-arvoisessa asemassa olevat etnisten vähemmistöjen jäsenet eivät pysty saavuttamaan samaa elintasoa, urakehitystä tai terveyden tasoa kuin valtaväestö johtuen siitä, että heidän lähtökohtansa ovat huonommat kuin valtaväestöllä.

Maissa, joissa tasa-arvoa on pyritty parantamaan positiivisella erityiskohtelulla - esimerkiksi varaamalla vähemmistöjen jäsenille paikkoja korkeakouluihin tai vaatimalla, että vähemmistöjen on oltava riittävästi edustettuina työpaikkojen henkilöstössä monet valtaväestön jäsenet ovat sitä mieltä, että erityiskohtelu tekee heistä rasismin uhreja. Heidän mielestään tasa-arvoa olisi se, että kaikille annettaisiin samat mahdollisuudet, sen jälkeen lopputulos olisi vain inmisestä itsestään kiinni. He eivät näe, että lopputulos ei ole vain ihmisestä kiinni: Hyvin usein valtaväestön asuinalueella on parempia kouluja, valtaväestöön kuuluvissa perheissä vanhemmilla on parempi koulutus ja tulotaso, mikä parantaa lasten mahdollisuuksia opiskella ja pärjätä opinnoissaan, osallistua erilaisiin harrastuksiin ja verkostoitua. Valtaväestölle on kertynyt varallisuutta, jonka avulla he voivat edelleen kerryttää varallisuuttaan ja siirtää sitä myös seuraaville sukupolville. Valtaväestön edustajat saavat parempaa palvelua terveydenhuollon palveluissa, tulevat useammin valituiksi avoimeen työpaikkaan ja niin edelleen. Ilman erityiskohtelua vähemmistöt jäävät yhä pahemmin jälkeen valtaväestöstä. 
Rasismintutkijat huomauttavatkin, että syrjintää tarkastellessa tulee katsoa seurauksia, ei mahdollisuuksia. (Bonilla-Silva 2006; Omi \& Winant 1994.)

Syrjintä mielletään usein rasismin synonyymiksi, ja rasismin suomalaisena vastineena käytetään toisinaan rotusyrjintää (Kortteinen \& Makkonen 2000, 10; Kielitoimiston sanakirja, s.v. rasismi; Puuronen 2011, 51; Sinokki 2017a, 11). Syrjinnän käsite on kuitenkin rasismin käsitettä suppeampi, sillä syrjintä-termi viittaa toimintaan tai toimimatta jättämiseen. Rasistiset ajatukset ja asenteet eivät sisälly siihen, eikä syrjinnällä yleensä ymmärretä myöskään toiseuttamisen kaltaisia, vaikeasti osoitettavia rasismin muotoja. (Aaltonen ym. 2009, 10; Cashmore 1996, 305-306; Kortteinen \& Makkonen 2000, 10.)

Lainsäädännössä (Yhdenvertaisuuslaki 2014/1325 § 14) syrjinnän kiellon yhteydessä mainitaan myös häirintä. Häirintää on se, jos jotain ryhmää tai sen jäseniä kohdellaan uhkaavasti, halventavasti, nöyryyttävästi tai loukkaavasti. Häirinnän ja syrjinnän ero on siis se, että häirinnän tarkoitus on loukata toista ihmistä, kun taas syrjinnän tarkoitus on ennemmin varmistaa oman ryhmän etuoikeudet - lopputulos voi silti olla sama.

Toiseuttamisen, syrjinnän ja häirinnän lisäksi on vielä muuta rasistista toimintaa, kuten alistamista, hyväksikäyttöä ja väkivaltaa. Termien väliset rajat eivät ole tarkkoja: Tönimistä voi ehkä kutsua häirinnäksi, mutta lyömistä ei, silloin kyse on väkivallasta. Alempi palkkataso on syrjintää, mutta kuinka paljon alempi palkkataso voi olla, että on jo asiallisempaa puhua hyväksikäytöstä?

\section{Ksenofobia}

Ksenofobia mainittiin 11 tekstissä, joista osa suomensi termin ulkomaalais-, muukalaistai vieraspeloksi tai -vihaksi. Teksteistä neljä määritteli termin. Niiden mukaan se tarkoittaa voimakkaan varauksellista ennakkoasennetta tai kielteistä suhdetta erilaisuuteen tai vieraan kulttuurin edustajiin (Helminen 1996, 40; Raittila 2004, 22; Raittila \& Kutilainen 2000, 6; Vehmas 2005, 97). Muut seitsemän tekstiä jättivät termin määrittelemättä. Esimerkiksi Raittila $(2007,50)$ kirjoittaa: "[V]aikka joukkoviestintä ei olekaan päävastuullinen suomalaisen yhteiskunnan ksenofobiasta, sillä lienee muihin ideologisin [sic] valtiokoneistoihin verrattuna parhaat mahdollisuudet purkaa rasismin ja muukalaispelon taustalla olevia kulttuurisia ajatusmalleja." Samoin kuin syrjintä, myös ksenofobia esiintyy usein rasismin rinnalla, tavallaan täydentämässä ilmiön kuvailua. Näin sitä käyttää muun muassa Luostarinen (2007, 20): "[K]oska suomalaisessa yhteiskunnassa esiintyy muukalaispelkoa ja rasismia, myös niille on annettava tilaa julkisuudessa."

Ksenofobia-termi tulee kreikan kielen sanoista xénos ( $\xi \varepsilon$ voc) eli muukalainen, vieras tai ulkomaalainen ja phóbos ( $\phi$ óßoৎ) eli pelko tai kammo. Fobia-pääte on tullut tutuksi psykologian oireluokituksesta, jossa se kuvaa suhteetonta pelkoa tai kauhua jotain usein kuvitteellista - uhkaa kohtaan. Ksenofobia ei kuitenkaan ole kliininen psykologinen termi, eikä sitä oikeastaan koskaan käytetä todellisessa fobia- tai kauhumerkityksessä. Yleensä sillä kuvataan etniseen vähemmistöön tai vierasperäisiin ihmisiin liittyvää tunnetta, johon sekoittuu vastenmielisyyttä, pelkoa ja vihaa. (Bleich 2011, 1586; Gindro 2003, 331; Makkonen 2000, 10; Puuronen 2011, 51; Tafira 2011, 115; Taguieff 2008, 223.) 
Ksenofobia-termin käyttöä kannattaa pohtia tarkasti. Hyvin usein sitä käytetään korvaamassa rasismi-sanaa, jolloin se toimii eufemismina (Banton 1996, 382; Makkonen 2000, 10; Tafira 2011, 114). Rasismin pukeminen kauniimpaan muotoon on kuitenkin ilmiön vähättelyä, ja lisäksi se hankaloittaa rasismin torjumista. Rasismi on ilmiö, joka muuntuu jatkuvasti ja on siksi hankala havaita, tunnistaa ja todentaa (Fitzgerald 2016, 11; Sundstrom \& Kim 2014, 33). Sitä ei tulisi entisestään hämärtää kaunistelevilla kiertoilmauksilla.

Toinen ongelma ksenofobia-termin kohdalla on se, että fobia-pääte tarkoittaa hallitsematonta pelkoa. Niinpä se antaa rasismiin syyllistyvälle ihmiselle mahdollisuuden puolustella omaa asennettaan väittämällä, että se on vain vieraan ihmisen aiheuttama pelkoreaktio, jolle hän ei voi mitään. Vastuu rasismista siirtyy rasistilta rasismin uhrille.

Ksenofobia-sanan käyttöä on todennäköisesti lisännyt se, että homokielteisyydestä käytetään vastaavanlaista termiä homofobia. Näitä kahta termiä ei kuitenkaan voi rinnastaa. Tuskin kukaan pitää homoja oikeasti pelottavina, minkä vuoksi sana saa homovastaisen ihmisen näyttäytymään naurettavana. Sen sijaan esimerkiksi muslimimaahanmuuttajiin liitetään usein todellisiksi koettuja uhkakuvia. Siksi ksenofobiasana antaa rasismille oikeutuksen: se nähdään osittain perusteltuna pelkona maahantulijoita kohtaan. (Taras 2012, 2-4, 18, 31, 118.)

Myös ksenofobia-termin alkuosaan liittyy ongelmia. Sana xénos pitää sisällään ajatuksen, että pelon kohde on muukalainen tai vieras. Näin päädytään alleviivaamaan, että tuo toinen ei todellakaan ole yksi meistä. Suomalainen tummaihoinen ihminen joutuu kokemaan muukalaispelkoa, Suomen romani tai saamelainen vierasvihaa.

Mediatutkimuksessakin näkyy, miten ksenofobia-sana voi hämärtää tutkijoiden käsitystä rasismista. Raittila ja Kutilainen $(2000,6)$ ja Vehmas $(2005,97)$ kirjoittavat, että ksenofobia eroaa rasismista siinä, että se "ei välttämättä perustu omasta kulttuurista eroavien ihmisten pitämiseen alempiarvoisina, vaan taustalla voivat olla ennakkoluulot uutta ja vierasta kohtaan". Tällainen eronteko ei kestä lähempää tarkastelua. Kuvitellaan, että henkilö A tuntee kielteistä suhtautumista ja/tai pelkoa henkilöä B kohtaan siksi, että tämä kuuluu toiseen, uuteen ja vieraaseen, omasta kulttuurista eroavaan ryhmään, ja että samassa tilanteessa A ei kokisi pelkoa tai kielteistä suhtautumista omaan ryhmäänsä kuuluvaa henkilöä kohtaan. Eikö A pidä silloin B:tä oman ryhmänsä jäseniä huonompana - siis alempiarvoisena? Eikö reaktio kerro siitä, että hän uskoo henkilön olevan jollain tavalla arveluttava tai epäluotettava? Eikö hänen asennoitumisensa siis ole rasistista? Miten ksenofobia sitten eroaa rasismista? Väittäisin, että ei mitenkään. Olemme vain sokeita sille, että jos toinen inminen koetaan uhkaavana tai pelottavana rodullistetun erilaisuuden perusteella, kyse on rasismista.

Ksenofobia-termin käyttö olisi hyvä rajoittaa vain sellaisiin tapauksiin, joissa tarkoitus on nimenomaan korostaa rasismiin liittyvää pelkoa. Sellaistakin rasismiin kietoutuu, sillä koemme kaikki erilaisia järjenvastaisia pelkoja - myös silloin kun kohtaamme ihmisiä muista etnisistä ryhmistä. Mutta jos ryhdymme perustelemaan pelkojamme toisen ihmisen kuvitteellisilla ominaisuuksilla, syyllistymme rasismiin. (Gindro 2003, 331; Ryynänen s.d.) 
Muukalaispelkoa tai -vastaisuutta yleisemmäksi on nykyään noussut maahanmuuttovastaisuus-sana. Siihen sisältyy kuitenkin vahva pyrkimys peittää puhujan todelliset vaikuttimet. Maahanmuuttovastainen ihminen tarkoittaa maahanmuutolla harvoin esimerkiksi Ruotsista tai Kanadasta tulevia maahanmuuttajia. Sen sijaan hän yleensä vastustaa turvapaikanhakijoita ja parempaa elintasoa etsiviä inmisiä ja samalla kaikkia, jotka ulkonäön tai vaatetuksen perusteella voisivat olla sellaisia - tai eivät ainakaan vaikuta "meiltä".

Vielä epärehellisempi on maahanmuuttokriittisyys-sana. Sen lanseerasivat perussuomalainen poliitikko Jussi Halla-aho ja muut Hommafoorumin oikeistopopulistiset kirjoittajat (Horsti 2013, 310). Mediatutkimuksen teksteihin se ilmestyi vuonna 2010 ja esiintyi niissä vielä vuonna 2013. Mari Maasilta $(2012,11)$ huomauttaa, että muun muassa Hommafoorumilla käydyn keskustelun nimeäminen kriittiseksi on harhaanjohtavaa, koska suurin osa siitä on todellisuudessa selkeän kielteistä ja itse asiassa toistelee varsin kritiikittömästi populistisia näkemyksiä. Populistit onnistuivat kuitenkin juurruttamaan sanan niin vahvasti keskusteluun, että se ilmestyi muutamaksi vuodeksi myös mediatutkimuksen kieleen. Toisinaan se varustettiin sitaattimerkeillä, mutta yhtä kaikki sillä kierrettiin tutkimusteksteissä sellaiset ilmaukset kuin pakolaiskielteisyys, muslimikielteisyys tai rasismi. (Ks. esim. Maasilta 2012; Mattlar 2010; Pöyhtäri, Haara \& Raittila 2013; Pöyhtäri \& Kantola 2013; Vehmas 2012).

\section{Käsitteiden väliset suhteet}

Hyvin usein rasismi ja siihen liittyvät käsitteet luetellaan teksteissä samanarvoisina, rinnakkaisina ilmiöinä. Teksteissä puhutaan esimerkiksi "rasistisiksi tulkituista tai toiseutta sisältävistä teksteistä" (Ahola, M. 2002, 163), "rasismin ja etnisen syrjinnän käsittelemisestä julkisuudessa" (Raittila \& Kutilainen 2000, 6) ja "rasismin ja ulkomaalaispelon leviämisestä" (Luostarinen 1992b, 13). Syntyy kuva, että on olemassa toisaalta rasismia ja toisaalta toiseuttamista, syrjintää tai ksenofobiaa, jotka eivät ole rasismia. Itse näen, että rasismi on yläkäsite, jonka alle kuuluvat rasismin ilmenemismuodot, kuten rodullistaminen, toiseuttaminen ja syrjintä, samoin kuin rasismin ideologia.

Riippuu tilanteesta, onko parempi käyttää rasismi-termiä, jolloin se kattaa koko ilmiökentän kaikkine ilmenemismuotoineen vai onko parempi yksilöidä jokin tai joitakin rasismin ilmenemismuotoja. Joka tapauksessa on tärkeää tehdä selväksi, että rasismin ilmenemismuodot ovat rasismia eivätkä jotain sen ulkopuolelle jäävää, vähemmän vakavaksi tulkittavaa.

\section{Rasismintutkimuksen hitaasti hälvenevä sokeus}

Mainitsin artikkelin alkupuolella, että rasismintutkimus on tuore tieteenala, joka edelleen muuttuu nopeasti. Sen haaste on, että se tutkii ilmiötä, jolle tutkijat itsekin ovat sokeita, sillä heidät on kasvatettu rasismin kyllästämässä maailmassa ja sosiaalistettu 
sen ajattelutapaan. Rasismi-ilmiön hidas kirkastuminen näkyy myös suomalaisessa mediatutkimuksessa: teksteihin pääsee mukaan rasistisuutta, joka paljastuu vasta ajan kanssa.

Vuonna 1996 julkaistussa kirjassa Etniset vähemmistöt, maahanmuuttajat, ulkomaalaiset - kuinka raportoida? Käytännön aineistoa journalisteille (Helminen 1996, 9) toimittajia ohjeistettiin näin: "[R]ehti ja täsmällinen journalismi ottaa kantaa perustelemattomiin rasistisiin ja muukalaisvihamielisiin ennakkoluuloihin ja syytteisiin" (kursivointi lisätty). Rasistiset ennakkoluulot ja muukalaisvihamielisyys olivat siis hyväksyttäviä niin kauan kuin ne olivat perusteltuja.

Samassa tekstissä todettiin, että kriittisyys on eri asia kuin muukalaisviha tai selkeä rasismi. Jos kuitenkin pohtii sanan kriittisyys käyttöä eri yhteyksissä, huomaa, että siihen sisältyy aina negatiivinen lataus. Sen näkee myös vaihtamalla sanoja: Tuskin kenellekään tulisi mieleen pohtia, että kriittisyys tamperelaisia kohtaan on eri asia kuin tamperelaisviha, sillä kriittisyys tamperelaisia kohtaan pitäisi sisällään ajatuksen, että tamperelaisuuteen liittyy jotain perustavanlaatuista huonoutta. Ja tamperelaisvihan kuvitteleminen edes hypoteettisena asiana tuntuu järjettömältä.

Vuonna 2008 islamia ja joukkoviestimiä käsittelevässä tutkimuksessa kirjoitettiin:

70 prosenttia suomalaisista on samaa mieltä sen kanssa, että "suomalaisten tulisi tehokkaasti varjella kulttuurinsa omaleimaisuutta yhä lisääntyvää kansainvälistymistä vastaan". [... K]ysymys lienee [kuitenkin] useimpien kohdalla vilpittömästä oman kulttuurin huolenpidosta [...] (Maasilta ym. 2008, 8.)

Oman kulttuurin varjeleminen kansainvälistymiseltä tai muilta kulttuureilta on oikeistopopulismin ahkerasti viljelemää retoriikkaa (Pöyhtäri \& Kantola 2013, 41-42). Siinä ei ole kyse vilpittömästä oman kulttuurin huolenpidosta vaan perusteettomista peloista - ja toisinaan niiden tietoisesta lietsonnasta. Esimerkiksi Espanjassa, IsossaBritanniassa ja Ranskassa maahanmuutto on jo vuosisatoja ollut huomattavasti suurempaa kuin Suomessa, mutta maiden kansallinen kulttuuri ei ole kadonnut mihinkään. Suurempi pelko oman kulttuurin katoamisesta lienee vähemmistöryhmillä, mutta heidän kulttuurinsa ei näissä tapauksissa ole huolen aiheena. Maahanmuuttajat ovat olleet uhka alueen kulttuurille vain silloin, kun he ovat saapuneet valloittajina ja pyrkineet tietoisesti hävittämään alueen alkuperäiskansojen kulttuurit. Turvapaikanhakijoiden ja pakolaisten rinnastaminen tällaisiin maahantunkeutujiin (sekin yksi oikeistopopulistien suosimista ilmauksista) on väärin.

Poimin yllä käsitellyt esimerkit aiemmista mediatutkimuksen teksteistä tietoisena siitä, että olen itse yhtä sokea omalle ja oman aikani rasismille ja teen siksi parhaillaan tekstiä, jonka rasistisuutta en pysty nyt näkemään. Meidän tutkijoiden ja toimittajien on hyväksyttävä se, että rasismin kohdalla teemme virheitä, joista tulemme tietoisiksi vasta jälkeenpäin. 


\section{Johtopäätöksiä ja pohdintaa}

Vuosina 1995-2000 tehdyt mediaa koskevat tieteelliset tutkimukset havaitsivat, että suomalaislehdissä vähemmistön edustajat esiintyivät useimmiten negatiivisessa valossa eikä heitä pidetty varteenotettavina asiantuntijoina edes heitä itseään koskevissa asioissa (Raittila \& Vehmas 2005, 29-30). Tämän jälkeen todettiin, että "avointa rasismia" ilmeni kuitenkin harvoin ja yleensä yleisönosastokirjoituksissa. Tämä johtopäätös, jonka mukaan suomalaislehdissä ilmenee "harvoin avointa rasismia", on jäänyt toistumaan media-alan tutkimuskirjallisuuteen. Ajatuksen taustalla on kyse rasismin jaottelusta avoimeen ja piilorasismiin. Avointa rasismia ovat selkeät rasistiset tapaukset, kuten väkivalta, tahallinen syrjintä ja suorasanainen nimittely. Vaikeammin havaittavat rasismin muodot - joista mediasisällön tehnyt toimittaja ei itsekään ole välttämättä tietoinen - ovat piilorasismia. Lehtiteksteissä ilmenevä vähemmistön vähättely ja ohittaminen ovat tämän jaottelun mukaisesti piilorasismia. Ongelma on se, että samaan aikaan kun tutkimukset luokittelevat nämä rasismin muodot ei-avoimiksi, ne jättävät niiden kohdalla pois termin rasismi ja ryhtyvät puhumaan esimerkiksi toiseuttamisesta tai me-he-asetelmista. On hyvä, että tekstit yksilöivät aiheensa tarkemmilla alakäsitteillä, mutta olisi yhtä lailla tärkeää mainita, että näissäkin tapauksissa on kyse rasismista. Muutoin syntyy vaikutelma, että on olemassa oikeaa rasismia ja sitten muita, vähemmän vakavia ilmiöitä.

Kuvio 2: Rasismin ilmenemismuotoja.

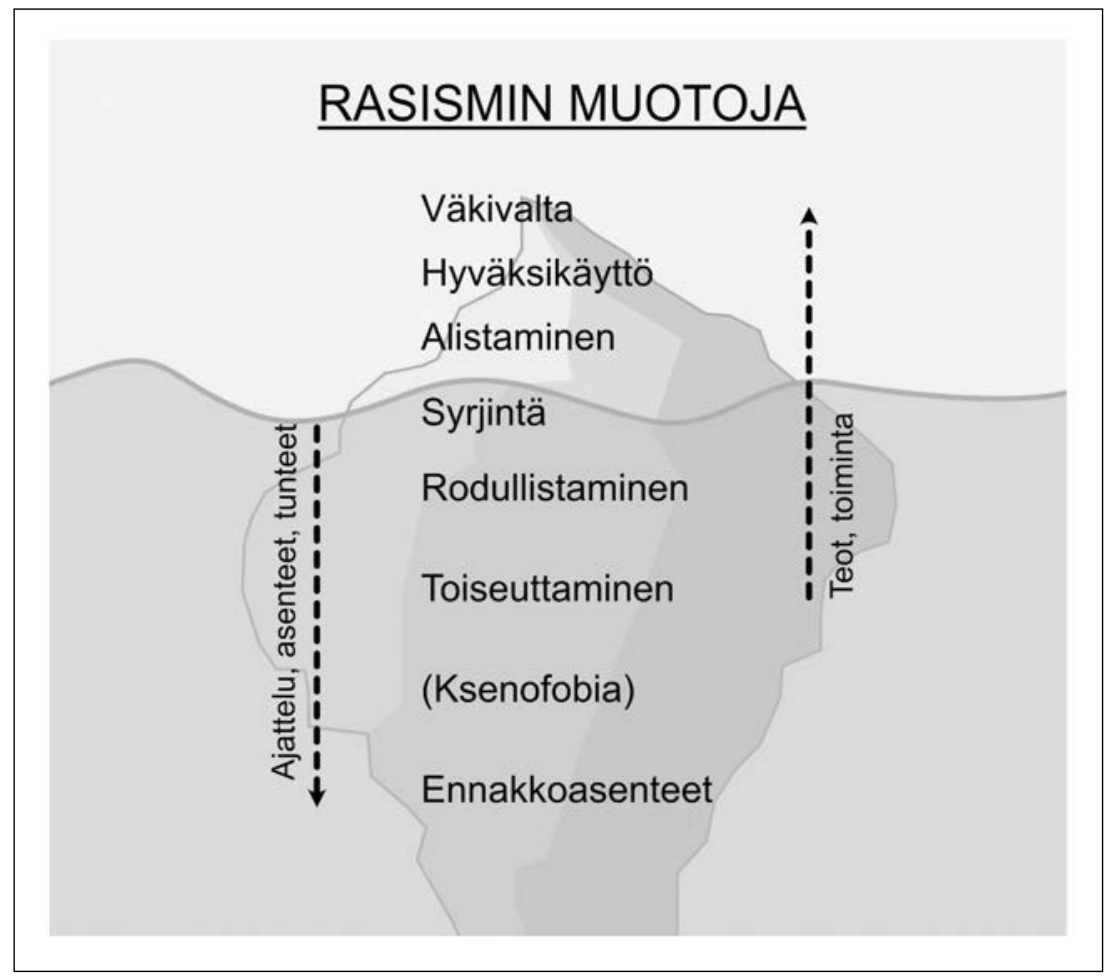


Olen kuviossa 2 listannut rasismin ilmenemismuotoja niin, että luettelon yläosassa on sellaisia rasismin muotoja, jotka ilmenevät tekoina. Mitä alemmas mennään, sitä vähemmän ilmiöt liittyvät tekoihin tai toimintaan ja sitä enemmän on kyse ihmisen sisäisistä ilmiöistä: ajattelusta, asenteisista ja tunteista. Niinpä ennakkoasenteet on mainittu listassa alimmaisena, kun taas väkivalta, hyväksikäyttö ja alistaminen ovat listan yläosassa. Väliin jää käsitteitä, jotka voivat kuvata yhtä hyvin toimintaa kuin asenteitakin: esimerkiksi syrjintä voi olla syrjiviä asenteita tai syrjivää käytöstä, ja toiseuttavan asennoitumisen lisäksi on olemassa toiseuttavia puheita ja käytöstä. Ksenofobia on suluissa, sillä se, kuten olen aiemmin maininnut, ei yleensä tarkoita rasismin ilmenemismuotoa vaan toimii rasismin eufemismina. Joissakin tapauksissa sillä voidaan kuitenkin tarkoittaa rasismiin liittyvää pelkoa.

Listan voi nähdä jäävuorena, josta haluttaisiin nähdä vain huippu. Konkreettiset, ilmeisimmät ja räikeimmät muodot saavat rasismi-nimen, mutta kun mennään pinnan alle, vaikeammin havaittaviin tunne- ja asennetason muotoihin, rasismi-sana jää helposti pois. Sen sijaan ryhdytään puhumaan esimerkiksi toiseuttamisesta, ksenofobiasta tai ennakkoasenteista. Samalla syntyy tunne, että asiassa ei ehkä olekaan enää kyse varsinaisesta rasismista.

Tällainen ajattelu on vaarallista, sillä valtaosa rasismista on juuri tuota vaikeasti havaittavaa, vedenalaista osaa. Siksi sillä on vähemmistöjen kannalta jopa suurempi merkitys kuin suorasanaisella solvaamisella tai selkeällä syrjinnällä. Tuo valtava pinnanalainen rasismi on se, jolle me kaikki olemme jossain määrin sokeita, joka on osa normaalia ajatteluamme ja joka pitää vähemmistöt ikuisesti yhteiskunnan marginaalissa, kritiikin kohteena.

On hyvin vaikeaa taistella sellaista ilmiötä vastaan, jota ei ole olemassa. Tutkijat ja toimittajat tietävät, että rasismi näkyy ja vaikuttaa yhteiskunnassamme, mutta silti he eivät löydä sitä mistään, mitä teemme. Koska emmehän me ole rasisteja. Ilmiön käsitteleminen muuttuu helpommaksi, kun ymmärrämme, että olemme. Satojen vuosien ajan valkoinen väestö ympäri maailmaa on kerännyt itselleen vaurautta ja poliittista ja taloudellista määräysvaltaa. Historian saatossa se on perustellut etuoikeutettua asemaansa muun muassa suuremmalla älykkyydellä, oikealla uskonnolla ja korkammalla sivistystasolla. Nyt se joutuu perustelemaan itselleen ja muille, miksi näin syntynyt järjestelmä on oikeutettu eikä sitä kannata muuttaa. Perustelut saavat väistämättä rasistisen luonteen: Syy on niissä muissa. Ne eivät vain osaa tai pärjää. Ne eivät ole ansainneet. Nekin pärjäisivät, jos yrittäisivät tai haluaisivat yhtä paljon kuin me. (Baltzar 2018, 81-83; Essed 1991, 11-14; Lehtonen 2009, 112; Omi \& Winant 1994, 69; Pitkänen 2017, 67-68.)

Meidän on voitava tunnistaa rasismi sielläkin, missä se tulee inhottavan lähelle itseä. Ei ole olemassa toiseuttamista, syrjintää, ennakkoluuloja tai ksenofobiaa, joissa ei olisi kyse rasismista. On olemassa rasismia ja sen loputtoman moninaisia, otteesta lipsuvia ilmenemismuotoja. Jos aikoo haastaa tuon monipäisen vihollisen, on uskallettava kutsua sitä sen oikealla nimellä. 


\section{Kiitokset}

Tätä tutkimusta ovat tukeneet Suomen Kulttuurirahaston Keski-Suomen rahasto ja Journalistisen kulttuurin edistämissäätiö.

\section{Kirjallisuus}

* Selvityksessä mukana olleet tekstit on merkitty asteriskilla.

Aaltonen, Milla; Joronen, Mikko \& Villa, Susan (2009). Syrjintä työelämässä. Pilottitutkimus työsuojelupiirien aineistosta. Helsinki: Syrjinnänseurantaryhmä, sisäasiainministeriö.

Adam, Heribert (2015). Xenophobia, asylum seekers, and immigration policies in Germany. Nationalism and Ethnic Politics 21:4, 446-464. https://doi.org/10.1080/13537113.2015.1095528

* Ahola, Eeva (2002). Romaniturvapaikanhakijat tv-uutisten kohteina. Teoksessa: Raittila, Pentti (toim.). Etnisyys ja rasismi journalismissa. Suomen Journalistiliitto, 128-144.

* Ahola, Mia (2002). Etnisyys urheilusivuilla: Sevillan yleisurheilun MM-kilpailujen käsittely iltapäivälehdissä. Teoksessa: Raittila, Pentti (toim.). Etnisyys ja rasismi journalismissa. Suomen Journalistiliitto, 162-182.

Anttonen, Ritva (2009). "Manne takaraivossa". Ennakkoluulot ja syrjintä suomalaisten romaniyrittäjien kokemana. Fenomenografinen tutkimus. Jyväskylän yliopisto.

Balibar, Étienne (1991a). Is there a "neo-racism"? Teoksessa: Balibar, Étienne \& Wallerstein, Immanuel (toim.). Race, nation and class. Ambiguous identities. London: Verso, 17-28. https://doi.org/10.1093/sf/72.2.578

Balibar, Étienne (1991b). Racism and crisis. Teoksessa: Balibar, Étienne \& Wallerstein, Immanuel (toim.). Race, nation and class. Ambiguous identities. London: Verso, 217-227. https://doi.org/10.1093/sf/72.2.578

Baltzar, Carmen (2018). Valkoinen ylivalta, uhrin retoriikka ja julkisen puheen laajempi ilmapiiri. Teoksessa: Kaartinen, Marjo (toim.). Vihan pitkät jäljet. Menneisyydestä, vainosta, vihasta ja siitä, mitä meidän olisi sille tehtävä. Vihan pitkät jäljet -hanke. Turun yliopisto, 74-84.

Banton, Michael (1996). Xenophobia. Teoksessa: Cashmore, Ellis (toim.). Dictionary of race and ethnic relations. London: Routledge, 382-383.

Banton, Michael \& Miles, Robert (1996). Racism. Teoksessa: Cashmore, Ellis (toim.). Dictionary of race and ethnic relations. London: Routledge, 308-312.

Bernasconi, Robert (2014). Where is xenophobia in the fight against racism? Critical Philosophy of Race 2:1, 5-19. https://doi.org/10.5325/critphilrace.2.1.0005

Blackburn, Daniel G. (2000). Why race is not a biological concept. Teoksessa: Lang, Berel (toim.). Race and racism in theory and practice. Lanham, MD: Rowman and Littlefield, 3-26.

Bleich, Erik (2011). What is Islamophobia and how much is there? Theorizing and measuring an emerging comparative concept. American Behavioral Scientist 55, 1581-1600. https://doi.org/10.1177/0002764211409387

Bonilla-Silva, Eduardo (2006). Racism without racists. Color-blind racism and the persistence of racial inequality in the United States. Lanham, MD: Rowman \& Littlefield Publishers.

Boréus, Kristina (2006). Discursive discrimination: a typology. European Journal of Social Theory 9:3, 405-424. https://doi.org/10.1177/1368431006065721

Bracalenti, Raffaele \& Braham, Peter (2003). Introduction. Teoksessa: Bolaffi, Guido; Bracalenti, Raffaele; Braham, Peter \& Gindro, Sandro (toim.). Dictionary of race, ethnicity and culture. London: Sage, x-xviii. https://doi.org/10.4135/9781446220375

Brown, Rupert (2010). Prejudice - Its social psychology. Chichester: Blackwell.

Bulmer, Martin \& Solomos, John (2004). Introduction: researching race and racism. Teoksessa: Bulmer, Martin \& Solomos, John (toim.). Researching race and racism. London: Routledge, 1-15. https://doi.org/10.4324/9780203643808

Cashmore, Ellis (1996). Racial discrimination. Teoksessa: Cashmore, Ellis (toim.). Dictionary of race and ethnic relations. London: Routledge, 305-306.

Coates, Rodney D. (2011). Covert racism in the U.S. and globally. Teoksessa: Coates, Rodney D. (toim.). Covert racism. Theories, institutions, and experiences. Leiden: Brill, 239-265.

https://doi.org/10.1163/ej.9789004203655.i-461.89 
Essed, Philomena (1991). Understanding everyday racism. An interdisciplinary theory. Newbury Park, CA: Sage.

Essed, Philomena (2004). Naming the unnameable. Sense and sensibilities in researching racism. Teoksessa: Bulmer, Martin \& Solomos, John (toim.). Researching race and racism. London: Routledge, 119-133.

Fitzgerald, Kathleen J. (2016). Recognizing race and ethnicity. Power, privilege, and inequality. Boulder, CO: Westview Press.

Gindro, Sandro (2003). Xenophobia. Teoksessa: Bolaffi, Guido; Bracalenti, Raffaele; Braham, Peter \& Gindro, Sandro (toim.). Dictionary of race, ethnicity and culture. London: Sage, 331-333. https://doi.org/10.4135/9781446220375

Goldberg, David Theo (1993). Racist cultures. Philosophy and the politics of meaning. Oxford: Blackwell.

* Haavisto, Camilla \& Kivikuru, Ullamaija (2009). Sulkevat sanat, avoimet kuvat. Teoksessa: Keskinen, Suvi; Rastas, Anna \& Tuori, Salla (toim.). En ole rasisti, mutta... Maahanmuutosta, monikulttuurisuudesta ja kritiikistä. Tampere: Vastapaino, 87-96.

* Heinonen, Ari (1995). Vahtikoiran omatunto : Journalismin itsesääntely ja toimittajat. Tampereen yliopisto.

* Helminen, Marjut (1996). Etniset vähemmistöt, maahanmuuttajat, ulkomaalaiset - kuinka raportoida? Käytännön aineistoa journalisteille. Helsinki: Suomen Journalistiliitto.

* Hiltunen, Anna-Kaisa (2007). Kaksinkertaisesti toiseutetuista sankarimaahanmuuttajattariksi : Tutkijaja lukijatulkinnat vertailussa. Teoksessa: Raittila, Pentti (toim.). Keskusteluja etnisyydestä mediassa: Suomalaisten, maahanmuuttajien ja tutkijoiden tulkintoja. Tampereen yliopisto, Journalismin tutkimusyksikkö, 107-130.

* Horsti, Karina (2000). Media ohittaa "toisen". Suomen mediatutkimus etnisyydestä, rasismista ja maahanmuutosta. Tiedotustutkimus 23:4, 79-87. Saatavilla: https://journal.fi/mediaviestinta/article/ view/61512 (luettu 14.11.2020).

* Horsti, Karina (2002). Maahanmuuttojournalismi - välivaihe monikulttuuriseen journalismiin. Teoksessa: Raittila, Pentti (toim.). Etnisyys ja rasismi journalismissa. Suomen Journalistiliitto, 109-127.

* Horsti, Karina (2005). Vierauden rajat. Monikulttuurisuus ja turvapaikanhakijat journalismissa. Tampere: Tampere University Press.

* Horsti, Karina (2009). Kyllä Suomeen yksi nainen mahtuu! Turvapaikanhakijat uhreina ja uhkana suomalaisessa julkisuudessa. Teoksessa: Keskinen, Suvi; Rastas, Anna \& Tuori, Salla (toim.). En ole rasisti, mutta... Maahanmuutosta, monikulttuurisuudesta ja kritiikistä. Tampere: Vastapaino, 77-85.

* Horsti, Karina (2013). Maahanmuuttajat mediamaisemassa. Teoksessa: Martikainen, Tuomas; Saukkonen, Pasi \& Säävälä, Minna (toim.). Muuttajat: Kansainvälinen muuttoliike ja suomalainen yhteiskunta. Helsinki: Gaudeamus, 301-317.

* Hurri, Merja (1992). Tervetuloa turvaan Suomeen! Pakolaisjournalismi, asenteet ja lähdekritiikki. Teoksessa: Sihvola, Jukka (toim.). Toimittaja ja pakolaiskysymykset. Journalismikriittisiä kannanottoja pakolaisasioiden käsittelystä suomalaisissa tiedotusvälineissä. Tampereen yliopiston täydennyskoulutuskeskus, 111-128.

Huttunen, Laura; Löytty, Olli \& Rastas, Anna (2005). Suomalainen monikulttuurisuus. Teoksessa: Rastas, Anna; Huttunen, Laura \& Löytty, Olli (toim.). Suomalainen vieraskirja. Kuinka käsitellä monikulttuurisuutta. Tampere: Vastapaino, 16-40.

* Hämeen-Anttila, Jaakko (2004). Kuvia ja mielikuvia. Teoksessa: Hämeen-Anttila, Jaakko (toim.). Islamin ja arabimaailman kuvat mediassa - seminaariraportti. Helsinki: Suomen Pakolaisapu, 7-10.

Isaksson, Pekka \& Jokisalo, Jouko (2005). Kallonmittaajia ja skinejä. Rasismin aatehistoriaa. Helsinki: Like; Suomen Rauhanpuolustajat.

Jaakkola, Magdalena (2005). Suomalaisten suhtautuminen maahanmuuttajiin vuosina 1987-2003. Helsinki: Työministeriö.

* Jerman, Helena (2009). Venäläiset tulivat: Tutkija kohtaa median kuvan maahanmuuttajista. Teoksessa: Keskinen, Suvi; Rastas, Anna \& Tuori, Salla (toim.). En ole rasisti, mutta... Maahanmuutosta, monikulttuurisuudesta ja kritiikistä. Tampere: Vastapaino, 97-105.

* Keskinen, Suvi (2009a). "Me" ja "muut"? Kunniaan liittyvä väkivalta median kuvauksissa. Teoksessa: Tauro, Tanja \& van Dijken, Marjo (toim.). Kunnia konfliktina: Näkökulmia ilmiön tunnistamiseen ja ennaltaehkäisyyn. Helsinki: Mannerheimin Lastensuojeluliitto, 16-29.

* Keskinen, Suvi (2009b). Pelkkiä ongelmia? Maahanmuutto poliittisen keskustelun kohteena. Teoksessa: Keskinen, Suvi; Rastas, Anna \& Tuori, Salla (toim.). En ole rasisti, mutta... Maahanmuutosta, monikulttuurisuudesta ja kritiikistä. Tampere: Vastapaino, 33-45. 
* Keskinen, Suvi (2010). Maahanmuuttokeskustelu ei ole yhden miehen varassa. Teoksessa: Kyrölä, Katariina (toim.). Journalismikritiikin vuosikirja 2010. Tampereen yliopisto, Journalismin tutkimusyksikkö, 61-64.

Kielitoimiston sanakirja. Saatavilla: https://www.kielitoimistonsanakirja.fi/ (luettu 15.11.2018).

* Kivikuru, Ullamaija; Maasilta, Mari \& Nikunen, Kaarina (2018). Johdanto. Teoksessa: Maasilta, Mari \& Nikunen, Kaarina (toim.). Pakolaisuus, tunteet ja media. Tampere: Vastapaino, 7-20.

Kortteinen, Juhani \& Makkonen, Timo (2000). Oikeutta rasismin ja syrjinnän uhreille. Etnisen syrjinnän ja rasismin vastainen käsikirja. Helsinki: Ihmisoikeusliitto.

Lehtonen, Mikko (2009). Olen suomalainen (Io sono finlandese). Teoksessa: Keskinen, Suvi; Rastas, Anna \& Tuori, Salla (toim.). En ole rasisti mutta... Maahanmuutosta, monikulttuurisuudesta ja kritiikistä. Tampere: Vastapaino, 109-115.

* Luostarinen, Heikki (1992a). Vaihduntakuvio. Teoksessa: Sihvola, Jukka (toim.). Toimittaja ja pakolaiskysymykset. Journalismikriittisiä kannanottoja pakolaisasioiden käsittelystä suomalaisissa tiedotusvälineissä. Tampereen yliopiston täydennyskoulutuskeskus, 129-152.

* Luostarinen, Heikki (1992b). Vanhan vainoojan poika. Teoksessa: Sihvola, Jukka (toim.). Toimittaja ja pakolaiskysymykset. Journalismikriittisiä kannanottoja pakolaisasioiden käsittelystä suomalaisissa tiedotusvälineissä. Tampereen yliopiston täydennyskoulutuskeskus, 1-39.

* Luostarinen, Heikki (2007). Tietoa, terapiaa ja turbaaneja? Suomalaisen journalismin reaktiot kasvavaan maahanmuuttoon. Teoksessa: Luostarinen, Heikki; Eskonen, Hanna; Horsti, Karina; Nikunen, Kaarina \& Pöyhtäri, Reeta (toim.). Maahanmuutto ja media. Eurooppalaista tutkimusta ja kotimaisia ennusteita. Tampereen yliopisto, Journalismin tutkimusyksikkö, 10-39.

Löytty, Olli (2005). Kuka pelkää mustavalkoista miestä? Toiseuttavan katseen rajat. Teoksessa: Löytty, Olli (toim.). Rajanylityksiä. Tutkimusreittejä toiseuden tuolle puolen. Tampere: Gaudeamus, 87-102.

* Maasilta, Mari (2012). Johdanto. Teoksessa: Maasilta, Mari (toim.). Maahanmuutto, media ja eduskuntavaalit. Tampere: Yliopistopaino, 7-22.

* Maasilta, Mari; Rahkonen, Juho \& Raittila, Pentti (2008). Islam suomalaisissa joukkoviestimissä. Tampereen yliopisto, Journalismin tutkimusyksikkö.

Makkonen, Timo (2000). Rasismi Suomessa 2000. Tutkimusraportti. Helsinki: Ihmisoikeusliitto.

Malik, Kenan (2008). Strange fruit. Why both sides are wrong in the race debate. Oxford: Oneworld.

* Mattlar, Markus (2010). Retoriikkaa ja rikostutkintoja - maahanmuuttokriitikko Jussi Halla-aho marginalisoitui häiriköksi. Teoksessa: Kyrölä, Katariina (toim.). Journalismikritiikin vuosikirja 2010. Tampereen yliopisto, Journalismin tutkimusyksikkö, 53-60.

* Melin, Harri (1992). Pakolaiskysymys ja julkisuus. Teoksessa: Sihvola, Jukka (toim.). Toimittajat ja pakolaiskysymykset. Journalismikriittisiä kannanottoja pakolaisasioiden käsittelystä suomalaisissa tiedotusvälineissä. Tampere: Tampereen yliopiston täydennyskoulutuskeskus, 41-53.

Miles, Robert (1994). Rasismi. Suom. Antero Tiusanen ja Juha Koivisto. Tampere: Vastapaino.

Murji, Karim \& Solomos, John (2005). Introduction: Racialization in theory and practice. Teoksessa: Murji, Karim \& Solomos, John (toim.). Racialization. Studies in theory and practice. Oxford: Oxford University Press, 1-27.

Omi, Michael \& Winant, Howard (1994). Racial formation in the United States. From the 1960s to the 1990s. New York: Routledge.

Pietikäinen, Sari (2000). Discourses of differentiation. Ethnic representations in newspaper texts. Jyväskylän yliopisto.

* Pietikäinen, Sari (2002). Etniset vähemmistöt uutisissa - käsitteitä ja aikaisempien tutkimusten kertomaa. Teoksessa: Raittila, Pentti (toim.). Etnisyys ja rasismi journalismissa. Tampere: Tampere University Press, 14-30.

* Pietikäinen, Sari \& Luostarinen, Heikki (1996). Vähemmistöt suomalaisessa julkisuudessa. Teoksessa: Dahlgren, Taina (toim.). Vähemmistöt ja niiden syrjintä Suomessa. Helsinki: Yliopistopaino, 171-198.

Pitkänen, Olli (2017). Rasismi ja huono usko. Teoksessa: Sinokki, Jani (toim.). Rasismi ja filosofia. Turku: Eetos, 59-71.

Puuronen, Vesa (2011). Rasistinen Suomi. Helsinki: Gaudeamus.

* Pöyhtäri, Reeta (2015). Vihapuhe haasteena uutismedialle ja journalismille. Teoksessa: Neuvonen, Riku (toim.). Vihapuhe Suomessa. Helsinki: Edita, 241-266.

* Pöyhtäri, Reeta (2018). Raiskausuutisesta vihapuheeseen: uutismedian eettistä harkintaa. Teoksessa: Maasilta, Mari \& Nikunen, Kaarina (toim.). Pakolaisuus, tunteet ja media. Tampere: Vastapaino, 92-126. 
* Pöyhtäri, Reeta; Haara, Paula \& Raittila, Pentti (2013). Johdanto. Teoksessa: Pöyhtäri, Reeta; Haara, Paula \& Raittila, Pentti (toim.). Vihapuhe sananvapautta kaventamassa. Tampere: Yliopistopaino, 15-25.

* Pöyhtäri, Reeta \& Kantola, Matleena (2013). Vihapuhe ja sananvapaus. Teoksessa: Pöyhtäri, Reeta; Haara, Paula \& Raittila, Pentti (toim.). Vihapuhe sananvapautta kaventamassa. Tampere: Yliopistopaino, 26-72.

* Raittila, Pentti (2002). Etniset aiheet, vähemmistöt ja niiden suhteet suomalaisessa journalismissa vuonna 2000. Teoksessa: Raittila, Pentti (toim.). Etnisyys ja rasismi journalismissa. Suomen Journalistiliitto, 31-108.

* Raittila, Pentti (2004). Venäläiset ja virolaiset suomalaisten toisina: tapaustutkimuksia ja analyysimenetelmien kehittelyä. Tampere University Press.

* Raittila, Pentti (2005). Seitsemän vuotta mediaseurantaa. Teoksessa: Raittila, Pentti (toim.). Etnisyyttä, rasismia ja dialogia sanomalehdessä ja Internetissä. Tampereen yliopisto, Journalismin tutkimusyksikkö, 5-10.

* Raittila, Pentti (2007). Etnisyyttä koskevien tekstien tulkintaa kouluissa ja keskusteluryhmissä. Teoksessa: Raittila, Pentti (toim.). Keskusteluja etnisyydestä mediassa: Suomalaisten, maahanmuuttajien ja tutkijoiden tulkintoja. Tampereen yliopisto, Journalismin tutkimusyksikkö, $11-52$.

* Raittila, Pentti (2009). Journalismin maahanmuuttokeskustelu: hymistelyä, kriittisyyttä vai rasismin tukemista? Teoksessa: Keskinen, Suvi; Rastas, Anna \& Tuori, Salla (toim.). En ole rasisti, mutta... Maahanmuutosta, monikulttuurisuudesta ja kritiikistä. Tampere: Vastapaino, 67-75.

* Raittila, Pentti \& Kutilainen, Tommi (2000). Rasismi ja etnisyys Suomen sanomalehdissä syksyllä 1999. Tampere: Journalismin tutkimusyksikkö.

* Raittila, Pentti \& Vehmas, Susanna (2005). Etnisyys ja rasismi sanomalehdissä 1999-2004 seurantatutkimusten yhteenvetoa ja arviointia. Teoksessa: Raittila, Pentti (toim.). Etnisyyttä, rasismia ja dialogia sanomalehdissä ja Internetissä. Tampere: Tampereen yliopisto, 11-32.

Rastas, Anna (2005). Rasismi. Oppeja, asenteita, toimintaa ja seurauksia. Teoksessa: Rastas, Anna; Huttunen, Laura \& Löytty, Olli (toim.). Suomalainen vieraskirja. Kuinka käsitellä monikulttuurisuutta. Tampere: Vastapaino, 69-116.

Ryynänen, Sanna (tulossa) Yes, but is it racism? Teoksessa: Communicative Space - Political Space: Proceedings of the 11th Central and Eastern European Communication and Media Conference CEECOM 2018. University of Szeged.

Scheinin, Martin (1996). Mitä on syrjintä? Teoksessa: Dahlgren, Taina; Kortteinen, Juhani; Lång, K. J.; Pentikäinen, Merja \& Scheinin, Martin (toim.). Vähemmistöt ja niiden syrjintä Suomessa. Helsinki: Yliopistopaino, 7-19.

Sinokki, Jani (2017a). Johdanto. Teoksessa: Sinokki, Jani (toim.). Rasismi ja filosofia. Turku: Eetos, 11-36.

Sinokki, Jani (2017b). Rasismin määritelmä. Teoksessa: Sinokki, Jani (toim.). Rasismi ja filosofia. Turku: Eetos, 271-287.

* Stenström, Bo (1995). Suvaitsevaisuus ja joukkoviestimet. MoniTori 3, 27-29.

Sundstrom, Ronald R. \& Kim, David Haekwon (2014). Xenophobia and racism. Critical Philosophy of Race 2:1, 20-45. https://doi.org/10.5325/critphilrace.2.1.0020

Tafira, Kenneth (2011). Is xenophobia racism? Anthropology Southern Africa 34, 114-121. https://doi.org/10.1080/23323256.2011.11500015

Taguieff, Pierre-André (2008). Racisme, racialisme, ethnocentrisme, xénophobie, antisémitisme et néoracisme: réflexions sur des termes problématiques. Teoksessa: La lutte contre le racisme, l'antisemitisme et la xenophobie. Année 2007. Paris: Commission nationale consultative des droits de l'homme, 216-245.

* Taira, Teemu (2008). Islamin muuttuva julkisuuskuva: Tapaustutkimus Helsingin Sanomista 1946-1994. Teoksessa: Martikainen, Tuomas; Sakaranaho, Tuula \& Juntunen, Marko (toim.). Islam Suomessa: Muslimit arjessa, mediassa ja yhteiskunnassa. Helsinki: Suomalaisen Kirjallisuuden Seura, 200-224.

Taras, Ray (2012). Xenophobia and islamophobia in Europe. Edinburgh: Edinburgh University Press.

Trepagnier, Barbara (2011). Silent racism. Teoksessa: Coates, Rodney D. (toim.). Covert racism. Theories, institutions, and experiences. Leiden: Brill, 353-364. https://doi.org/10.1163/ej.9789004203655.i-461.123

van den Berghe, Pierre L. (1996). Race - as synonym. Teoksessa: Cashmore, Ellis (toim.). Dictionary of race and ethnic relations. London: Routledge, 296-298. 
van Dijk, Teun A. (1999). Discourse and racism. Discourse Q Society 10:2, 147-148.

* Vehmas, Susanna (2005). Rasismi ja etnisyys sanomalehdissä keväällä 2004. Teoksessa: Raittila, Pentti (toim.). Etnisyyttä, rasismia ja dialogia sanomalehdissä ja Internetissä. Tampereen yliopisto, 97-175.

* Vehmas, Susanna (2012). Maahanmuuttokirjoittelu sanomalehdissä. Teoksessa: Maasilta, Mari (toim.). Maahanmuutto, media ja eduskuntavaalit. Tampere: Yliopistopaino, 116-135.

* Wickström, Jarkko \& Maasilta, Mari (2012). Maahanmuutto ja vaalit televisiojulkisuudessa. Teoksessa: Maasilta, Mari (toim.). Maahanmuutto, media ja eduskuntavaalit. Tampere: Yliopistopaino, 136-162.

Wodak, Ruth \& Reisigl, Martin (2015). Discourse and racism. Teoksessa: Tannen, Deborah; Hamilton, Heidi E. \& Schiffrin, Deborah (toim.). The handbook of discourse analysis (2., uudistettu painos). Chichester: Wiley Blackwell, 576-596. https://doi.org/10.1002/9781118584194.ch27

Yhdenvertaisuuslaki 2014/1325. Annettu Helsingissä 30.12.2014.

\section{Viitteet}

$1 \quad$ Hirsch, Afua (2018). I've had enough of white people who try to deny my experience. The Guardian 24.1.2018. Saatavilla: https://www.theguardian.com/commentisfree/2018/jan/24/white-people-tvracism-afua-hirsch (luettu 6.8.2018).

2 Hirsch, Afua (2018). Closet racists get a mouthpiece. Pledge 19.1.2018. Saatavilla: https://www. youtube.com/watch?v=tqPKwudnPVw (katsottu 8.8.2018). 